\title{
INFLUENCE OF HUMAN HB-EGF SECRETED FORM ON CELLS WITH DIFFERENT EGFR AND ErbB4 QUANTITY
}

\author{
O. I. KRYNINA ${ }^{凶}$, N. V. KOROTKEVYCH, A. J. LABYNTSEV, \\ S. I. ROMANIUK, D. V. KOLYBO, S. V. KOMISARENKO \\ Palladin Institute of Biochemistry, National Academy of Sciences of Ukraine, Kyiv; \\ @e-mail: olyakrynina@gmail.com
}

Received: 18 July 2019; Accepted: 13 August 2019

\begin{abstract}
HB-EGF is one of the most potent ligands of EGFR and ErbB4 receptors. This growth factor plays a pivotal role in many cellular processes, but its effect differs from one cell type to another and remains not fully understood. The aim of this work was to investigate the dependence between the rate of HB-EGF mediated cell proliferation and activation of EGFR and ErbB4 receptors. Therefore, the effects of human recombinant sHB-EGF (rsHB-EGF) on the proliferation of cell lines with different EGFR and ErbB4 quantity and ratio, as well as activation of the MARK-cascade p38 and ERK1/2 (p42/44) kinases, were analyzed. For comparison, a similar study of the effect of native sHB-EGF secreted by human histiocytic lymphoma cells U937 during co-cultivation with different cell lines was performed. It was proved that cell proliferation in response to $S H B-E G F$ depends not only on the quantity but also on the ratio of EGFR and ErbB4. It was shown that signaling through ErbB4 is associated with activation of p38 kinase and signaling through EGFR associated with activation of ERK1/2 (p42/44) kinase. We assume the existence of two different mechanisms for $s H B$ EGF-mediated stimulation of cell proliferation, and the simultaneous launch of these mechanisms provides a maximal proliferative response. The results of this study support the feasibility of creating anti-proliferative drugs that target ErbB4.
\end{abstract}

Ke y wo rds: sHB-EGF, recombinant protein, EGFR and ErbB4, cell lines, proliferation, MAPK signaling pathway.

$\mathrm{T}$ his study investigated the functioning of heparin-binding epidermal growth factor-like growth factor (HB-EGF) that participates in a variety of normal and pathological processes in the organism. Foremost, HB-EGF is involved in the development and functioning of heart, skin and liver regeneration, blastocyst implantation, smooth muscle cell hyperplasia, tumor progression, pulmonary hypertension and neurodegenerative diseases [1]. This wide spectrum of biological activities makes HB-EGF and its receptors promising targets for the creation of new drugs for different therapeutic purposes.

HB-EGF was first discovered in the culture of human monocytes and macrophages. Later HB-EGF was purified from the conditioned media of the human myeloid leukemia cell line U937 [2] and classified as a member of the epidermal growth factor family. HB-EGF is synthesized as a membrane-anchored precursor molecule (proHB-EGF) containing signal, propeptide, heparin-binding, EGF-like, juxtamembrane, transmembrane and cytoplasmic regions [3]. ProHB-EGF can be cleaved by disintegrin and metalloproteases (ADAMs) or matrix metalloproteinases (MMPs) with the formation of soluble HB-EGF (sHB-EGF) and a carboxyl-terminal fragment containing the transmembrane and cytoplasmic segments (HB-EGF-CTF) [4].

HB-EGF binds with EGF receptors (EGFRs), known as HER (human epidermal growth factor receptor) or ErbB (erythroblastic leukemia viral oncogene homolog). HB-EGF interaction with EGFR (ErbB1) and ErbB4 causes their dimerization and autophosphorylation. ErbB2 and ErbB3 receptors can participate in sHB-EGF signal transduction only in the form of heterodimeric complexes with EGFR 
(ErbB1) or ErbB4 [5]. Interaction of the HB-EGF $\mathrm{N}$-terminal heparin-binding sequence with heparan sulfate proteoglycans stabilizes the EGF-like domain in a complex with a receptor and provides proper functioning of growth factor [6]. HB-EGF binding to ErbB receptors leads to its dimerization and subsequent activation of Ras/MAPK/ERK, PI3K/Akt, JAK/STAT, NF- $\kappa B$, PLC $\gamma /$ PKC signaling pathways. These pathways play an important role in processes of growth and proliferation, adhesion and migration, differentiation and survival (apoptosis inhibition), and their excessive activation can cause destabilization of cell functioning and malignant transformations [7].

HB-EGF-CTF internalizes from the plasma membrane through the endoplasmic reticulum to the nucleus, where it can bind transcription repressors PLZF (promyelocytic leukemia zinc finger protein) or Bcl6 and cause its export out from the nucleus. As a result, degradation of repressors in the cytoplasm increase expression of proteins, the functional effect of which can be coupled with sHB-EGF action. For example, enhancement of cyclins expression leads to activation of cellular proliferation [8, 9].

In past years, scientists have developed antitumor drugs that inhibit activation of ErbB receptors monoclonal antibodies to the extracellular domain of EGFR (cetuximab, panitumumab) or ErbB2 (trastuzumab), or that block the tyrosine-kinase function of EGFR (erlotinib, gefitinib). However, prolonged treatment with these drugs can cause undesirable side effects and the loss of sensitivity to them [10].

To improve sHB-EGF/EGFR-targeted therapy it is necessary to expand our understanding of mechanisms of implementation of growth factor biological activity, including regulation of expression of HB-EGF and its receptors, and find differences in the functioning of various types of ErbBs.

It is well known that EGFR activation as a consequence of interaction with HB-EGF plays an important role in stimulation of cell proliferation. However, the influence of HB-EGF interaction with the ErbB4 receptor in the regulation of cell proliferation remains unclear. Several studies provide evidence that activation of this receptor can either inhibit cell proliferation $[11,12]$ or lead to its stimulation $[13,14]$.

This work aimed to investigate the effect of human recombinant sHB-EGF (rsHB-EGF) on proliferation and activation of signaling pathways in various cell lines with a different quantity and ratio of EGFR and ErbB4. To prove the potency of rsHBEGF we also performed similar experiments with the U937 cell line that actively secretes a significant amount of native sHB-EGF in growth medium using a co-culturing technique. New data about the influence of HB-EGF interaction with different types of ErbB receptors and activation of appropriate signaling pathways on cell proliferation have not only fundamental importance for science, but may be applied to developing new, effective treatments for a variety of human diseases.

\section{Materials and Methods}

Maintenance of eukaryotic cell cultures. Mouse fibrosarcoma cell line L929a, immortalized green monkey kidney cell line Vero, embryonic BALB/c mouse fibroblast cell line 3T3, A431 human epidermoid carcinoma cells and U937 cell culture were obtained from the Bank of Cell Lines of R.E. Kavetsky Institute of Experimental pathology, oncology and radiobiology of the National Academy of Sciences of Ukraine (Kyiv, Ukraine). Cells were cultured in RPMI-1640 medium with L-glutamine (Sigma Aldrich, St. Louis, MO, USA), 5-10\% fetal bovine serum (FBS) (Gibco, Big Cabin, OK USA) and antibiotic-antimycotic solution (penicillin, streptomycin, amphotericin $\mathrm{B}$ ) in $5 \% \mathrm{CO}_{2}$ atmosphere. For cocultivation experiments, L929a, Vero, 3T3 and A431 cells were seeded in 24-well plates to obtain 70\% confluency. On the next day, the culture medium was changed to PanSerin 401 culture medium (HyClone, Logan, UT, USA) and cells were starved for $24 \mathrm{~h}$. U937 cells were seeded at $0.5-1 \times 10^{5}$ cells per well in $3 \mu \mathrm{m}$ Millicell cell culture inserts (Merck Millipore, Lansdale, PA, USA) and cultivated with tested cell cultures for $24 \mathrm{~h}$. To compare mitogenic effect L929a, Vero, 3T3 and A431 cells were treated with $1 \mu \mathrm{g} / \mathrm{ml} \mathrm{rsHB}$-EGF for 24 hours. Then the numbers of L929a, Vero, 3T3 and A431 cells in control and test wells were calculated. Trypan blue staining [15] was used to discriminate between viable and dead cells and determine the number of viable cells present in a cell suspension. To confirm the HB-EGF specificity of interaction with its receptor, the EGFR tyrosine kinase inhibitor AG1478 was used at $1 \mu \mathrm{M}$. MMP inhibitor GM6001 was used at $100 \mu \mathrm{M}$ to restrict the formation of endogenous sHB-EGF.

Recombinant proteins production. Human rsHB-EGF and its fluorescent derivative mCherryrsHB-EGF were purified from E. coli BL21 Rosetta (DE3) that was obtained earlier [16, 17]. Expression 
of recombinant proteins was induced by $1 \mathrm{mM}$ isopropyl $\beta$-D-1-thiogalactopyranoside (Thermo Fisher, Dreieich, Germany). Cells were lysed by sonification using Labsonic M ultrasonic homogenizer (Sartorius, Göttingen, Germany). Proteins were purified by affinity chromatography using a Ni-NTA agarose column (Sigma Aldrich, St. Louis, MO, USA). The efficiency of purification was qualified by SDSPAGE using a Mini-PROTEAN electrophoresis system (Bio-Rad, Hercules, CA, USA) [18].

Flow cytometry. L929a, Vero, 3T3 and A431 cells were grown to confluence and were detached from plastic Petri dishes with 30 mM EDTA in phosphate buffered saline (PBS) by incubation for $10 \mathrm{~min}$ at $37^{\circ} \mathrm{C}$. Cells were pelleted by centrifugation at $1000 \mathrm{rpm}$ for $10 \mathrm{~min}$, resuspended in PBS with 1\% bovine serum albumin (BSA) and $0.01 \% \mathrm{NaN}_{3}$ and counted. For each sample, $3 \times 10^{5}$ cells were used. Cells were incubated with $10 \mu \mathrm{g}$ mCherry-rsHBEGF or monoclonal antibodies to EGFR or ErbB4 (1:500) and FITC-conjugated anti-mouse antibodies (1:200) for 15 min at $4{ }^{\circ} \mathrm{C}$ (both antibodies from Sigma Aldrich, St. Louis, MO, USA). After incubation, cells were washed twice and resuspended in PBS with $1 \% \mathrm{BSA}$ and $0.01 \% \mathrm{NaN}_{3}$. The fluorescence intensities on FL1 and FL3 channels were measured with a Coulter Epics XL flow cytometer (Beckman Coulter, Hightstown, NJ, USA).

Evaluation of cell motility by scratch assay. $3 \mathrm{~T} 3$ cells were grown to $75-80 \%$ confluency on $24-$ well plates. Then the cell monolayer was scratched with a new $200 \mu$ l pipette tip and gently washed with RPMI-1640 medium to remove detached cells. Wells were replenished with fresh RPMI-1640 medium without FBS. To the appropriate wells, $1 \mu \mathrm{g} / \mathrm{ml}$ rsHB-EGF, $100 \mu \mathrm{M}$ GM6001 or $1 \mu \mathrm{M}$ AG1478 was added. Cells were grown for $24 \mathrm{~h}$ and photographed on a microscope CX22 (Olympus, Tokyo, Japan).

Enhanced chemiluminescence (ECL) western blot. Proteins from SDS-PAGE gels were transferred to nitrocellulose membranes. Membranes were blocked with 5\% skim milk powder in PBS for $2 \mathrm{~h}$ at $25{ }^{\circ} \mathrm{C}$. The membranes were incubated with the following antibodies from Santa Cruz Biotechnology Inc. (Dallas, TX, USA): anti-p38 antibody (1:1000), anti-phospho-p38 antibody (1:1000), anti-ERK 1/2 (p42/44) antibody (1:1000), anti-phospho-ERK1/2 (p42/44) antibody (1:1000), and anti- $\beta$-actin antibody (1:5000) in PBS with $1 \%$ skim milk powder at $4{ }^{\circ} \mathrm{C}$ overnight. The membranes were washed with $0,04 \%$ Tween 20 in PBS (PBS-T) three times for 10 min at room temperature and incubated with anti-mouse IgG (Fc specific)-peroxidase antibodies (Sigma Aldrich, St. Louis, MO, USA) for $1 \mathrm{~h}$ at $37^{\circ} \mathrm{C}$. After another cycle of membrane washing, proteins were visualized by incubation of the membranes in substrate solution containing $100 \mathrm{mM}$ Tris- $\mathrm{HCl}$, $0.025 \%$ luminol, $0.003 \%$ coumaric acid, and $0.035 \%$ $\mathrm{H}_{2} \mathrm{O}_{2}$ and then exposed to autoradiographic film for fixed periods of time. For the second ECL analysis, membranes were incubated in $0.2 \mathrm{M}$ glycine solution $(\mathrm{pH} 2.0)$ twice with a 1 min time interval in between and then left for another $30 \mathrm{~min}$ at $37^{\circ} \mathrm{C}$ with intensive shaking. After stripping, membranes were washed twice in PBS-T and repeatedly blocked with 5\% skim milk powder in PBS.

Statistical analysis. Analysis of flow cytometry data was performed using FCS Express V3 software (De Novo Software, Glendale, CA, USA). To determine the mean fluorescence intensity the subset of $1 \times 10^{4}$ events was used.

The mean values characterizing mitogen-induced cell proliferation were calculated based on 4 independent experiments of the viability test. The reliability of the differences between the mean values was determined by Student's $t$-test $(P<0.05)$ using Origin9 software (OriginLab Corporation, Northampton, MA, USA).

\section{Results and Discussion}

Confirmation of rsHB-EGF activity. Assessment of rsHB-EGF biological activity was carried out by determination of its ability to stimulate 3T3 cell monolayer recovery in the scratch assay. To confirm the specificity of rsHB-EGF mediated EGFR activation we used the tyrosine-kinase inhibitor AG1478. To eliminate the effects of autocrine sHBEGF that might be secreted into the medium, cells were treated with the MMP inhibitor GM6001.

The obtained results confirmed the mitogenic activity of rsHB-EGF because the addition of $500 \mathrm{ng} / \mathrm{ml}$ of rsHB-EGF to the culture medium accelerated cell motility and/or growth that led to decreases of the gap area (Fig. 1). Addition of GM6001 showed no significant effect on cell proliferation and migration potential because of the lower concentration of sHB-EGF that can be formed after shedding from the plasma membrane of 3T3 cells. Inhibition of EGFR activity by AG1478 caused decreased 3T3 cell motility and growth rates in the presence of rsHB-EGF that confirmed the specificity of rsHBEGF action. 


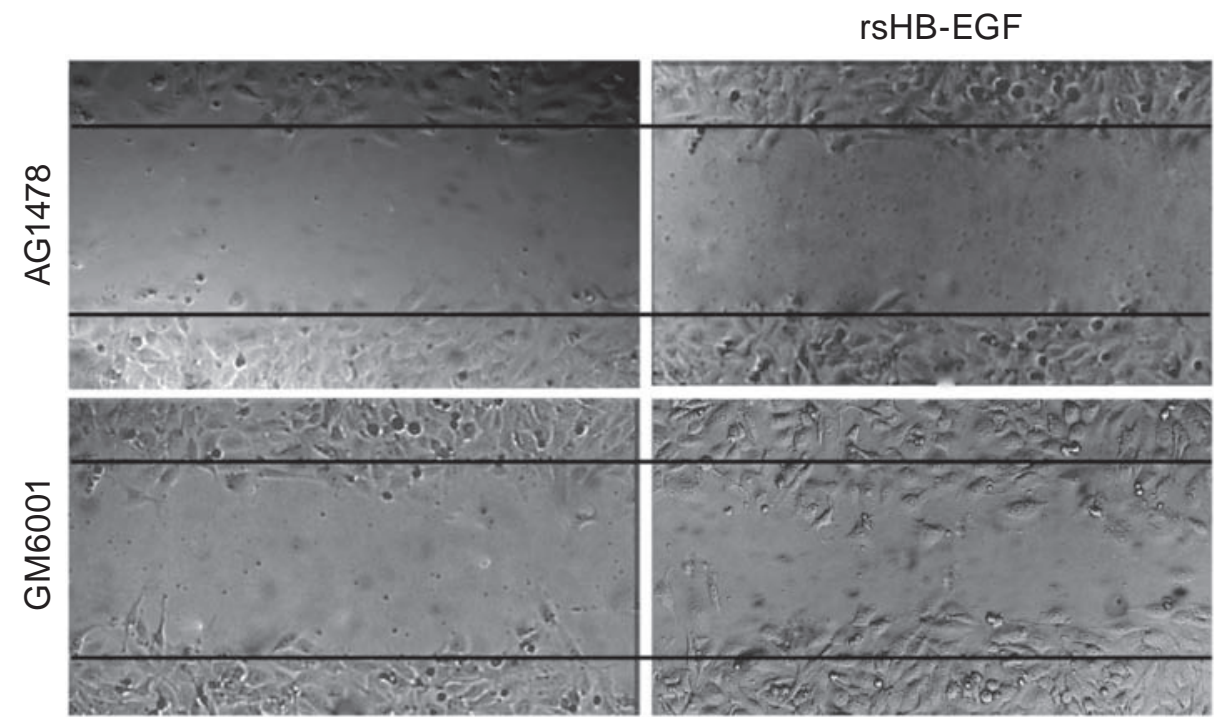

Fig. 1. Effect of rsHB-EGF on 3 T3 fibroblast monolayer recovery in the scratch assay with the addition of an EGFR inhibitor (AG1478) or MMP inhibitor (GM6001). Left panels are before rsHB-EGF; right panels are after rsHB-EGF addition. EGFR, epidermal growth factor receptor; MMP, matrix metalloproteinase; rsHBEGF, recombinant soluble heparin-binding epidermal growth factor-like growth factor

Evaluation of EGFR and ErbB4 receptors on the plasma membrane of different cell lines. It is known that the realization of sHB-EGF biological activity is dependent on binding EGFR and ErbB4. So, it is necessary to evaluate the number of these receptors present on the cell surface. We chose 4 different cell lines - L929a (mouse fibrosarcoma), Vero (immortalized kidney epithelial cells of green monkey), 3T3 (mouse embryonic fibroblasts) and A431 (human epidermoid carcinoma cells). The overall level of sHB-EGF receptors was investigated by flow cytometry using the fluorescently labeled derivative of rsHB-EGF (mCherry-rsHB-EGF) [17]. It was shown that binding of mCherry-rsHB-EGF to L929a and Vero cells was lower compared to 3T3 cells, and especially lower compared to A431 cells.

To more precisely determine the expression level of EGFR and ErbB4 on the plasma membrane, cells were incubated with monoclonal antibodies to these receptors and the corresponding FITC-labeled conjugate and analyzed by flow cytometry. The obtained results confirmed the significant overexpression of EGFR on A431 cells and the slight amount of both types of sHB-EGF receptors (i.e., EGFR and ErbB4) on L929a and Vero cells (Fig. 2, A). Interestingly, that correlation of receptors was different for all cell lines (Fig. 2, B). ErbB4 receptors predominated on the surface of L929a and Vero cells (60-70\%), whereas $3 \mathrm{~T} 3$ cells had approximately the same amount of EGFR and ErbB4. A431 cells were characterized by the almost complete absence of ErbB4 compared to EGFR.

Determination of rsHB-EGF mediated proliferation of various cell lines. To estimate the ability of rsHB-EGF to induce the proliferation process, the L929a, Vero, 3T3 and A431 cells were treated with $1 \mu \mathrm{g} / \mathrm{ml}$ rsHB-EGF for 24 hours and counted under a microscope. The trypan blue cell viability assay [15] was used to control cell viability during the experiment. As a positive control, the tested cell lines were co-cultured with U937 cells that actively secrete sHB-EGF into the medium. To block the formation of endogenous sHB-EGF, the cells were incubated with $100 \mu \mathrm{M}$ GM6001. Assay data showed that the natural sHB-EGF synthesized by U937 cells (Fig. 3, B) and its recombinant derivative (Fig. 3, A) had similar effects on the tested cell cultures. Addition of exogenous sHB-EGF stimulated the growth of 3T3 and A431 cell lines that correlated with the expression levels of sHB-EGF receptors.

Activation of p38 and ERK 1/2 (p42/44) MAPK kinases in different cell lines mediated by rsHB$E G F$. The MAP kinase pathway is the major cascade involved in the regulation of cell proliferation, migration and differentiation under mitogenic stimuli. ERK 1/2 (p42/44) and p38 are the central and important molecules of classical and alternative branches of the pathway, the phosphorylation of 

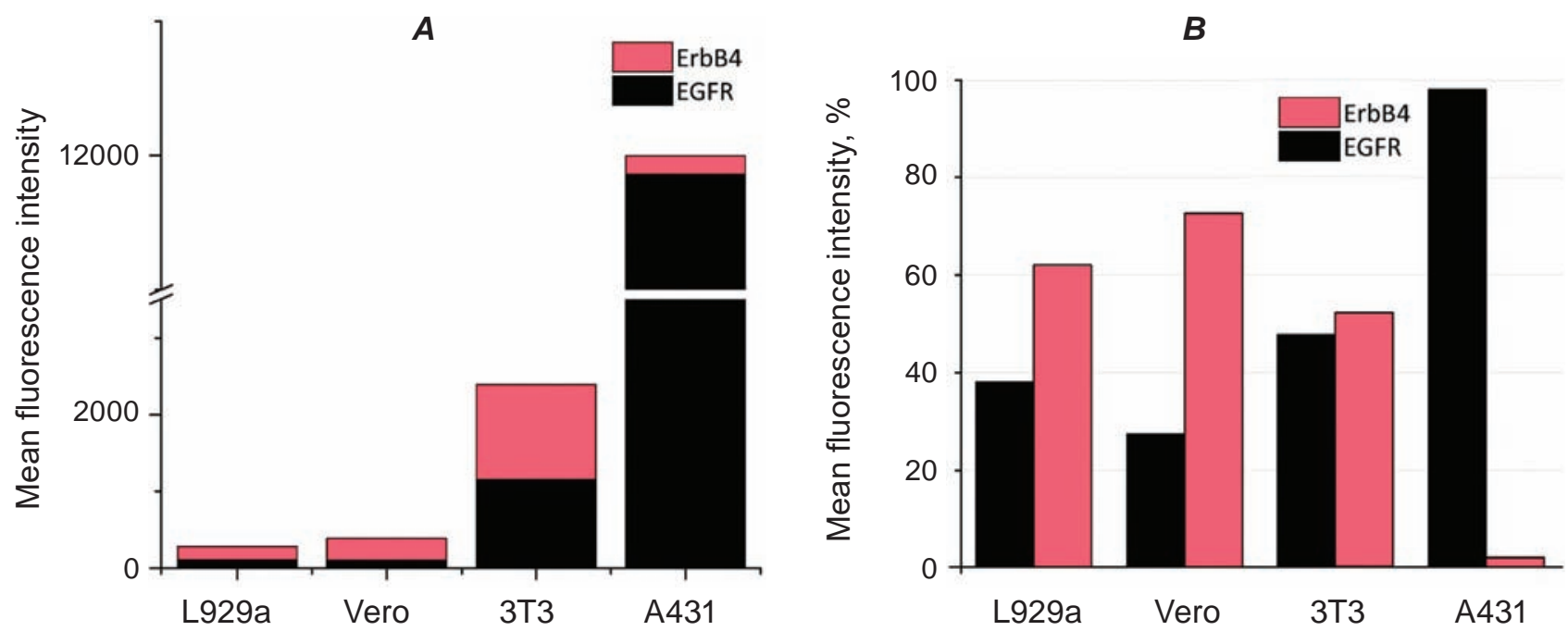

Fig. 2. Quantity and ratio of SHB-EGF receptors on the plasma membrane of L929a, Vero, 3T3 and A431 cells, defined by flow cytometry using monoclonal antibodies to EGFR and ErbB4: (A) absolute values of the fluorescence intensity; (B) relative values of the fluorescence intensity, expressed in percentages. EGFR, epidermal growth factor receptor; ErbB4, receptor tyrosine kinase 4; rsHB-EGF, recombinant soluble heparinbinding epidermal growth factor-like growth factor

$\boldsymbol{A}$

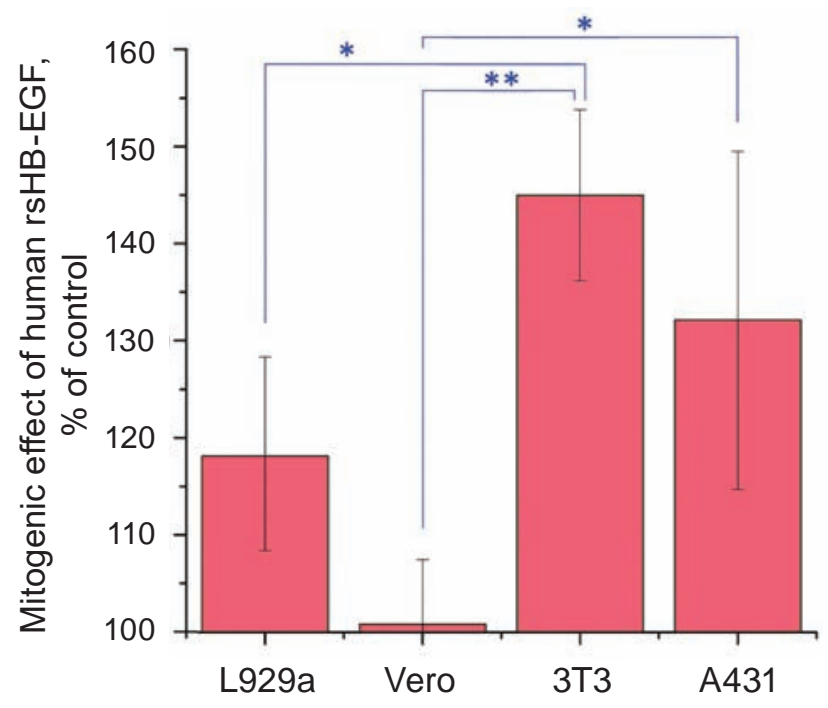

$B$

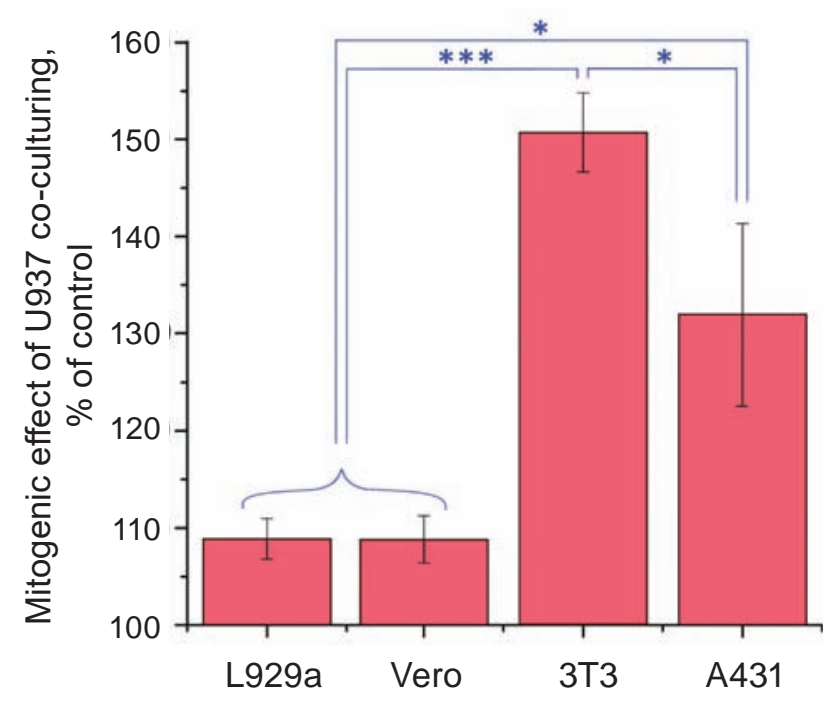

Fig. 3. Mitogenic activity of L929a, Vero, $3 T 3$ and A431 cells treated with (A) recombinant sHB-EGF (rsHB-EGF) and (B) native $S H B-E G F$, secreted into the medium by U937 cells during co-cultivation. $* P<0.05$; ${ }^{* *} P<0.01 ;{ }^{* * *} P<0.001$. sHB-EGF, soluble heparin-binding epidermal growth factor-like growth factor

which directly depends upon upstream activation of growth factor receptor, and is necessary for subsequent transmittance of signal to nuclear transcription factors [19]. To determine the dependence between quantity and ratio of sHB-EGF receptors on L929a, Vero, 3T3 and A431 cell lines and MAPK links activation, we examined the effect of rsHB-EGF on the phosphorylation of p42/44 and p38 MAPK by ECL western blot analysis using antibodies specific for the phosphorylated forms. Treatment of A431 cells with rsHB-EGF mainly stimulated p42/44 phosphorylation (Fig. 4). Incubation of 3T3 with rsHB-EGF led to increased phosphorylation of both p42/44 and p38 signaling molecules. For L929a and Vero cells 


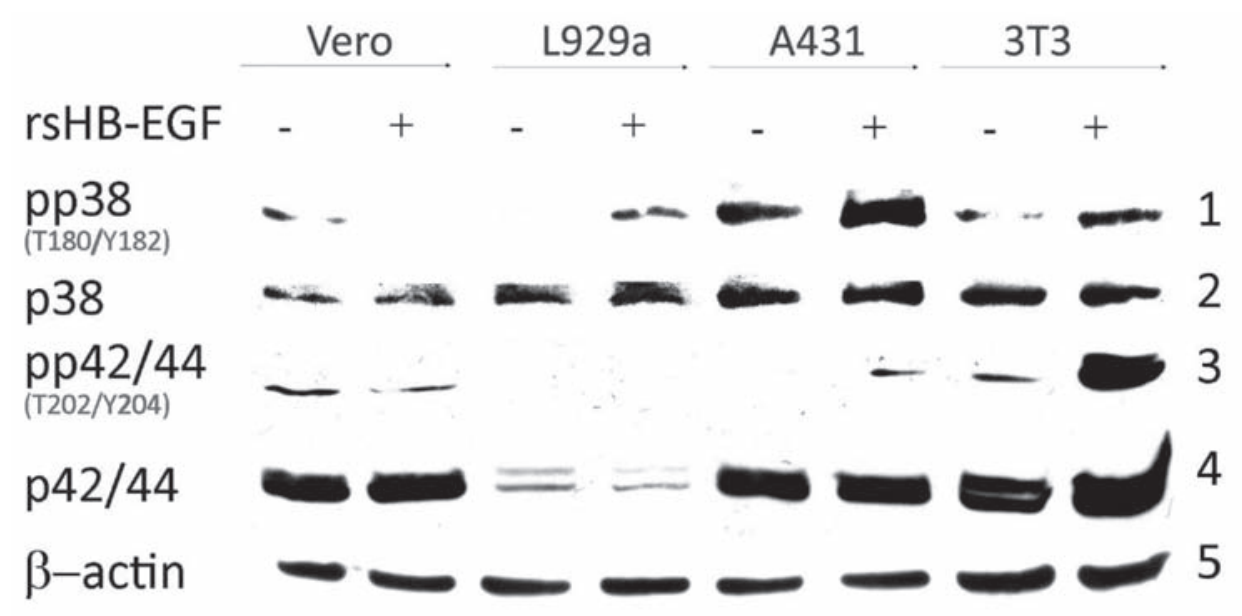

Fig. 4. Effect of rsHB-EGF on p38 ERK1/2 (p42/44) kinase activation in Vero, L929a, A431 and $3 T 3$ cell lines. 1 - a phosphorylated form of p38, 2 - total p38, 3 - a phosphorylated form of p42/44 (ERK1/2), 4-total p42/44 (ERK1/2), 5 - $\beta$-actin. rsHB-EGF, recombinant soluble heparin-binding epidermal growth factor-like growth factor

the changes concerned only the p38 kinase, the phosphorylated form of which appeared in L929a cells but was absent in Vero cells. Probably, in the case of Vero cells GM6001 did not completely block the formation of endogenous sHB-EGF, because it inhibits only several MMPs, so ADAM proteinases that can also shed sHB-EGF from plasma membrane remained active. A possible reason that Vero cells practically did not respond to the mitogenic stimuli was that the addition of rsHB-EGF caused receptor desensitization.

In this study we proved that our recombinant derivative of sHB-EGF is the biological analog of its wild form, that can specifically bind with EGFR and ErbB4 on the cell surface, activate phosphorylation of p38 and p42/44 kinase of the MAPK pathway and promote cell growth and survival. Secondly, cells of various cell lines (L929a, Vero, 3T3 and A431) differ in the levels of sHB-EGF receptor representation on the plasma membrane and as a result, they react differently to the rsHB-EGF treatment. We consider these differences below in more detail.

Vero and L929a cells are characterized by the lowest quantity of sHB-EGF receptors, as most of them make ErbB4 receptors. The growth response of these cells to recombinant and native sHB-EGF was insignificant and accompanied by changes of $\mathrm{p} 38 \mathrm{ki}-$ nase phosphorylation. BALB/c 3T3 cells have high and nearly equal expression levels of both EGFR and ErbB4 receptors, simultaneous activation of p38 and p42/44 MAP kinases and effective proliferation after sHB-EGF treatment. Addition of sHB-EGF to the A431 cell line that strongly overexpresses EGFR also intensifies the cell proliferation rate but causes phosphorylation of p42/44 MAP kinases. These data suggest that ErbB4 signaling connected with p38 kinase phosphorylation and EGFR signaling leads to p42/44 kinase phosphorylation.

According to our results, cell lines with the highest sHB-EGF receptor expression level have a more evident proliferation response. These results support the idea that the sensitivity of the cells to the action of growth factors from the EGF family depends on the quantity of its receptor presented on the cell membrane and EGFR plays a pivotal role in the regulation of proliferation process. However, it is probably not all that clear, since 3T3 cells had 10 times less EGFR receptors than A431 cells, but they more actively (or at least equally) proliferated in the presence of sHB-EGF. Probably, ErbB4 mediated signaling activates complementary pathways of the MAPK cascade and can implement an auxiliary stimulation proliferation triggered by EGFR autophosphorylation. In this case, expression of a large amount of both receptors is advantageous because this can sustain cell viability using different mechanisms, and therefore the proliferation rate is determined not only by the quantity of sHB-EGF receptors but also by the ratio of their types. It is possible that the maximum proliferative response of 3T3 cells that had the same ratio of sHB-EGF receptors can be explained by the formation of EGFR/ErbB4 
dimers, the activation of which leads to more effective stimulation of growth and division processes.

Besides the fact that EGF receptors can form dimers in different combinations, they can also bind different ligands: HB-EGF, epidermal growth factor, transforming growth factor- $\alpha$, betacellulin, amphiregulin, epiregulin and 4 types of neuregulins. Each growth factor does not act independently and affects the functioning of others, creating a wide range of possible biological effects that are implemented through EGF receptor signaling.

Each type of EGF receptor can have several isoforms that differ in their functional specialization, binding affinity to one or another ligand, and expression level in various tissues. The existence of at least 4 such isoforms for the ErbB4 receptor has been shown and all of them diversely implicated to different signaling pathways and maintained proliferation or migration [20]. The interaction of the EGF receptor with a ligand and its activation can be affected by specific antagonists, for example, the recently described glycoprotein MIF that is capable of blocking EGFR activation [21] or by the processes of receptor methylation, that facilitate high-affinity ligand binding [22].

Conclusion. Thus, the regulation of such important cell functions as growth, proliferation, migration, differentiation and survival, that can be mediated by EGF receptors and their ligands, including the HB-EGF, is a very complex, multilevel signaling system using a multitude of thin preventing mechanisms, and therefore it is very difficult to study its individual components.

The results of this study showed that HB-EGF interaction with both EGFR and ErbB4 stimulates cell proliferation, and it is probably realized through different signaling mechanisms. The proliferation rate is determined not only by the quantity of sHBEGF receptors but also by the ratio of their types. The maximum proliferation rate occurs at the 1:1 ratio of EGFR:ErbB4, that can be implemented through EGFR/ErbB4 dimer formation. In contrast to EGFR, the significance of ErbB4 as a potential therapeutic target remains mostly unexplored, even though ErbB4 is overexpressed or mutated in many solid tumors [23]. The results of this study support the feasibility of creating anti-proliferative drugs that target ErbB4.

\section{ВПЛИВ СЕКРЕТОРНОЇ ФОРМИ НВ-EGF ЛЮДИНИ НА КЛІТИНИ 3 РІЗНОЮ КІЛЬКІСТЮ ТА СПІВВІДНОШЕННЯМ РЕЦЕПТОРІВ EGFR I ErbB4}

\author{
О. І. Криніна ${ }^{\varpi}$, Н. В. Короткевич, \\ А. Ю. Лабинцев, С. І. Романюк, \\ Д. В. Колибо, С. В. Комісаренко
Інститут біохімії ім. О. В. Палладіна НАН України, Київ;
凶e-mail: olyakrynina@gmail.com

HB-EGF $\epsilon$ одним із найефективніших лігандів EGFR та ErbB4 рецепторів. Цей ростовий фактор відіграє важливу роль у багатьох клітинних процесах, проте його ефект відрізняється для різних типів клітин і залишається неповністю вивченим. Метою цієї роботи було дослідити залежність між НВEGF-індукованою проліферацією клітин та активацією рецепторів EGFR і ErbB4. Для цього було проаналізовано вплив рекомбінантного аналога sHB-EGF людини (rsHB-EGF) на проліферацію клітин різних ліній, що мають різну кількість і співвідношення рецепторів EGFR i ErbB4, а також на активацію p38 та ERK1/2 (р42/44) кіназ МАРК-каскаду в цих клітинах. Для порівняння проведено аналогічні дослідження щодо впливу природного sHB-EGF, який виділявся клітинами гістоцитної лімфоми людини U937 за кокультивування 3 клітинами різних ліній. Встановлено, що інтенсивність проліферації клітин у відповідь на дію sHBEGF залежить не тільки від кількості, а й від співвідношення рецепторів EGFR i ErbB4. Показано, що сигналінг через рецептор ErbB4 пов'язаний 3 активацією кінази р38, а сигналінг через рецептор EGFR - 3 активацією кінази ERK1/2 (p42/44). Зроблено припущення про існування двох різних механізмів стимулювання проліферації клітин під впливом sHB-EGF, одночасний запуск яких обумовлює максимальну проліферативну відповідь клітин. Результати цього дослідження свідчать на користь доцільності створення антипроліферативних препаратів, націлених на рецептор ErbB4.

К люч ч в рекомбінантний протеїн, рецептори EGFR та ErbB4, клітинні лініі, проліферація, МАРКсигнальний шлях. 


\section{References}

1. Murphrey MB, Varacallo M. Biochemistry, Epidermal Growth Factor Receptor. Treasure Island (FL): StatPearls Publishing, 2019.

2. Higashiyama S, Abraham JA, Miller J, Fiddes JC, Klagsbrun M. A heparin-binding growth factor secreted by macrophage-like cells that is related to EGF. Science. 1991; 251(4996): 936-939.

3. Higashiyama S, Lau K, Besner GE, Abraham JA, Klagsbrun M. Structure of heparin-binding EGF-like growth factor. Multiple forms, primary structure, and glycosylation of the mature protein. J Biol Chem. 1992; 267(9): 6205-6212.

4. Higashiyama S, Nanba D. ADAM-mediated ectodomain shedding of HB-EGF in receptor cross-talk. Biochim Biophys Acta. 2005; 1751(1): 110-117.

5. Singh B, Carpenter G, Coffey RJ. EGF receptor ligands: recent advances. F1000Res. 2016; 5. pii: F1000 Faculty Rev-2270.

6. Higashiyama S, Abraham JA, Klagsbrun M. Heparin-binding EGF-like growth factor stimulation of smooth muscle cell migration: dependence on interactions with cell surface heparan sulfate. J Cell Biol. 1993; 122(4): 933940.

7. Lindsey S, Langhans SA. Epidermal growth factor signaling in transformed cells. Int Rev Cell Mol Biol. 2015; 314: 1-41.

8. Hirata Y, Ogasawara N, Sasaki M, Mizushima T, Shimura T, Mizoshita T, Mori Y, Kubota E, Wada T, Tanida S, Kataoka H, Kamiya T, Higashiyama S, Joh T. BCL6 degradation caused by the interaction with the C-terminus of proHB-EGF induces cyclin D2 expression in gastric cancers. Br J Cancer. 2009; 100(8): 1320-1329.

9. Ozeki K, Tanida S, Morimoto C, Inoue Y, Mizoshita T, Tsukamoto H, Shimura T, Kataoka H, Kamiya T, Nishiwaki E, Ishiguro H, Higashiyama S, Joh T. Telmisartan inhibits cell proliferation by blocking nuclear translocation of ProHB-EGF C-terminal fragment in colon cancer cells. PLoS One. 2013; 8(2): e56770.

10. Roskoski R Jr. The ErbB/HER family of proteintyrosine kinases and cancer. Pharmacol Res. 2014; 79: 34-74.

11. Iwamoto R, Mine N, Mizushima H, Mekada E. ErbB1 and ErbB4 generate opposing signals regulating mesenchymal cell proliferation during valvulogenesis. J Cell Sci. 2017; 130(7): 1321-1332.
12. Liu Y, Song L, Ni H1, Sun L, Jiao W, Chen L, Zhou Q, Shen T, Cui H, Gao T, Li J. ERBB4 acts as a suppressor in the development of hepatocellular carcinoma. Carcinogenesis. 2017; 38(4): 465-473.

13. Hoesl C, Röhrl JM, Schneider MR, Dahlhoff M. The receptor tyrosine kinase ERBB4 is expressed in skin keratinocytes and influences epidermal proliferation. Biochim Biophys Acta Gen Subj. 2018; 1862(4): 958-966.

14. Xu J, Gong L, Qian Z, Song G, Liu J. ERBB4 promotes the proliferation of gastric cancer cells via the PI3K/Akt signaling pathway. Oncol Rep. 2018; 39(6): 2892-2898.

15. Strober W. Trypan blue exclusion test of cell viability. Curr Protoc Immunol. 2001; 21(1): 1-2.

16. Korotkevych NV, Kolybo DV, Labyntsev AJ. Obtaining recombinant secretory form of human HB-EGF and perspectives of its application in biotechnology. Biotechnologia Acta. 2010; 3(4): 44-54. (In Ukrainian).

17. Korotkevych NV, Labyntsev AJ, Kolybo DV, Komisarenko SV. Obtaining and characterization of recombinant fluorescent derivatives of soluble human HB-EGF. Biotechnologia Acta. 2014; 7(2): 46-53. (In Ukrainian).

18. Schägger H, von Jagow G. Tricine-sodium dodecyl sulfate-polyacrylamide gel electrophoresis for the separation of proteins in the range from 1 to 100 kDa. Anal Biochem. 1987; 166(2): 368-379.

19. Lin CC, Lee IT, Hsu CH, Hsu CK, Chi PL, Hsiao LD, Yang CM. Sphingosine-1-phosphate mediates ICAM-1-dependent monocyte adhesion through p38 MAPK and p42/p44 MAPK-dependent Akt activation. PLoS One. 2015; 10(3): e0118473.

20. Junttila TT, Sundvall M, Määttä JA, Elenius K. Erbb4 and its isoforms: selective regulation of growth factor responses by naturally occurring receptor variants. Trends Cardiovasc Med. 2000; 10(7): 304-310.

21. Zheng Y, Li X, Qian X, Wang Y, Lee JH, Xia Y, Hawke DH, Zhang G, Lyu J, Lu Z. Secreted and O-GlcNAcylated MIF binds to the human EGF receptor and inhibits its activation. Nat Cell Biol. 2015; 17(10): 1348-1355.

22. Liao HW, Hsu JM, Xia W, Wang HL, Wang YN, Chang WC, Arold ST, Chou CK, Tsou PH, Yamaguchi H, Fang YF, Lee HJ, Lee HH, Tai SK, Yang MH, Morelli MP, Sen M, Ladbury JE, Chen CH, Grandis JR, Kopetz S, 
Hung MC. PRMT1-mediated methylation of the EGF receptor regulates signaling and cetuximab response. J Clin Invest. 2015; 125(12): 45294543.
23. Rauf F, Festa F, Park JG, Magee M, Eaton S, Rinaldi C, Betanzos CM, Gonzalez-Malerva L, LaBaer J. Ibrutinib inhibition of ERBB4 reduces cell growth in a WNT5A-dependent manner. Oncogene. 2018; 37(17): 2237-2250. 